DOI https://doi.org/10.36059/978-966-397-242-8-15

Науменко Н. В.,

доктор філологічних наук, професор, професор кафедри іноземних мов професійного спрямування Національного університету харчових технологій, м. Київ

\title{
ВЕРЛІБРИСТИКА ВАСИЛЯ ГОЛОБОРОДЬКА В АСПЕКТІ КУЛЬТУРОЗНАВЧОГО ДОСЛІДЖЕННЯ
}

\begin{abstract}
Анотація. у статті виконано культурологічний аналіз вільновіршових творів Василя Голобородька, грунтованих на інтерпретації образів різних мистецтв - кераміки, скульптури, образотворчого мистецтва, живопису, графіки, дитячого малюнка. Виявлено, що концепти зазначених мистецтв перебувають у стані взаємопроникнення, а вільна віршова форма, за рахунок нерівномірного, «неспокійного» темпоритму, сприяє їх нестандартному осмисленню реципієнтами. По-перше, символіка керамічного виробу, будучи введеною в розповіді про подіі повсякденного життя, під пером Голобородька кристалізується у правічних бінарних філософемах «порожнеча - наповненість», «реальне - ілюзорне», «повсякденне - незвичайне» і відтак зумовлює погляд на текст вірша з позицій «золотого перерізу». Унаслідок такого аналізу визначено, що апріорі сталий (для метричного віршування) кульмінаційний пункт твору, позначений точкою «золотого перерізу», у вільному віршуванні В. Голобородька змінює місце відповідно до гармонійності складо- та строфоподілу, акцентування та кількості слів у рядку. Отже, до творення «пуанту» вірша залучається дедалі ширший словесний ряд, а також більша кількість мистецьких прийомів. Під кутом зору синтезу мистецтв установлено: змальовуючи індивідуальну художню картину світу, автор у переважній більшості віршів тяжіє до застосування головних прийомів дитячого «наївного» малювання (специфічного графічного вираження, техніки олівцевого, зокрема одноколірного, малюнка, динамічної зміни декорацій), тим самим включаючи візуальні елементи у нескінченний космічний рух. Співвідношення культурологічних елементів у Голобородьковому верлібрі, незалежно від взаємодіі в ньому стильових домінант, від тематики та
\end{abstract}


проблематики окремо взятого твору, дає підстави визначити його як особливий метажанр, усередині якого відбуваються синхронні та діахронні шукання в галузі поетичної форми, по-новому трактується традиційна образність та створюється нова.

\section{Вступ}

Про «Київську школу» як феномен сучасної української поезії можна говорити в кількох аспектах: як про суто поетичне явище, головною ознакою якого стала свобода творення; як про групу молодих нонконформістів, життєвим вектором яких була свобода волі в усіх її виявах; як про експериментальну психологічну спробу жити інакше, аніж інші покоління, жити так, ніби все відбувається у вільній незалежній державі; як про братство творців, головним і надзвичайним завданням яких була сама поезія. Тому верлібр став не просто версифікаційною домінантою поетів Київської школи, а й символом свободи.

3 верлібротворчістю «Київської школи» в українську поезію увійшов непідробний драматизм народного життя. Через слово поступово відроджується слов'янська міфопоетична свідомість; відбувається повернення до первісної основи буття. Усе це зумовило появу незвичних доти жанрових гатунків вільного вірша: поезія-літопис («Русь червлена», «Саркофаг: сторінка майбутнього літопису» В. Кордуна, «Літо літописує» В. Голобородька, «Спорудження храму» М. Григоріва), поезія-малюнок («Хлопчик малює літо» В. Голобородька), поезія-замовляння, поезія-витвір народного рукомесла, симультанна поезія, витримані у ключі народнопісенної образності поезії-діалоги та полілоги. Фольклоризм як першооснова верлібристики виявляється тут не лише на внутрішньому, а й на зовнішньому рівнях.

Матеріалом для культурознавчого дослідження в цій роботі $\epsilon$ творчість Василя Голобородька, яка за провідні «речові» деталі має витвори народного рукомесла - кераміку, вишиванки, мережива, витинанки. Усі їх поєднує образ домівки - «священного простору» [див. 17, с. 229; 29, с. 273]. Олюднені уявою поета, речі вводяться в символічний «четвертий вимір».

Верлібри В. Голобородька вирізняються 3-поміж усього масиву лірики 70-80-х років XX століття конгеніальністю фольклорній поезії, творчим переосмисленням її традиційних образів, символіки та атрибутики народних свят, зокрема веденням діалогу з об’єктами 
природи. Вони привертають увагу завдяки потужним і розмаїтим фольклорним конотаціям: казковій сюжетності, діалогізму замовлянь, метафоричності загадок. Своїми «верлібрами-скалками» [22, с. 95-97] - фрагментарними, однак при цьому синкретичними, поет спонукає читача не тільки споглядати красу буття та задумуватися над його суттю, а думати, аналізувати, «дивитися в корінь». Для цього, на думку авторки цієї роботи, потрібна саме верліброва (народнопісенна, розмовна, «очуднена») тональність вислову, адже вона дає читачеві імпульс до співтворчості, до спільного пошуку істини.

\section{1. Синтез культурних концептів \\ у творенні образу ужиткової речі}

Людинуз давніх-давен оточують речі, які полегшують та водночас прикрашають її життя. І. Кант назвав речі «другою природою», і тому закономірно, що річ для людини стала не просто «помічником», а й художнім образом, створюючи грунт для розвитку поетичного мислення. Одна й та сама річ у різних культурах набуває різних символічних значень, при цьому лишаючись частиною мікрокосмосу індивіда. Притаманне всім людям символічне світобачення, подібно до вчення суфізму - «релігії, яка з'явилася, щоб примирити всі релігії» [26, с. 222], - примирює всі можливі значення одного й того самого слова на позначення речі.

у першому підрозділі йтиметься про інтерпретацію В. Голобородьком символіки керамічного виробу - важливого «документа культурного розвитку», за яким пізнається мова, писемність, світоглядні, зокрема міфопоетичні уявлення українського народу. За легендою, саме 3 червоної глини Бог виліпив першу людину - Адама. Цей сюжет став провідним у значній частині космогонічних епосів, і відтак глину почали вважати першоматеріалом, із якого почалося життя.

Керамічний виріб послужив основою для формування поняття символу: в Давній Греції цим словом спочатку називали частину глиняного черепка, яку під час розлуки залишали собі, а іншу

віддавали коханому. При зустрічі половинки з'єднували (грец. SYMBALLO), відновлюючи ціле [14, с. 10]. Тому символ - це завжди розділення єдиного та єднання двоїстості.

Витвір керамічного мистецтва виходить за межі звичайної ужиткової речі, стає поетичним образом-символом, у трактуванні 
якого можуть співіснувати концепти різних культур. Концептуальні риси нанесеного на виріб орнаменту, передусім ритмічність і повторюваність, отримують потужний естетичний потенціал у словесному, насамперед вільновіршовому, творі завдяки повторюваності та ритмічності віршових рядів, якими первісний орнамент візуалізується у свідомості реципієнта.

Мета цього підрозділу роботи - з'ясувати специфіку перетворення символічного концепту «річ» із видовими найменуваннями на особливий складник культурологічної образності в ліриці окремо взятого поета.

Однією із ключових реалій художнього світу В. Голобородька виступає глечик, керамічний виріб, уживаний для зберігання рідких харчових продуктів - молока, сироватки, квасу, меду тощо [див. 8, с. 55], звідки виникло чимало прислів"їв: «Яка глина, такий і глечик», «У новому глечику й вода холодніша», «Прислів'я в розмові як солодкий мед у глечику». Отже, першим символічним значенням деталі «глечик», яке виявляється іще до прочитання тексту вірша, $€$ «оберіг», зокрема й збереження людиною свого єства:

А може, ми - дерева, / тільки наша самоназва - люди?

Все наше людське, безперечно, / виявляється у наших вчинках $i$ думках, / а не тому тільки, що наша самоназва люди...(«Самоназва»).

«Самоназва» як термін, запозичений із лінгвістики (етноніміки), отримує значне філософське навантаження. Поняття сутності речей, їхніх форми та змісту, античні діалектичні категорії «порожнечі та наповненості» заломлюються крізь мотив керамічного виробу:

Глечик тоді глечик, коли воду в ньому

зберігають чи п'ють із нього. Чи ж буде глечик

глечиком тоді, коли він порожній?..

Отже, єдино правильною сутністю речі (та й людини) є наповненість їі буття: «Думаймо і робімо все / по-людському, що людьми не самоназиватися, / а ними бути!» [5, с. 168].

Символіка керамічного виробу, скристалізована у бінарних філософемах «порожнеча - наповненість», «реальне - ілюзорне», «повсякденне - незвичайне», виростає з казкової образності перших віршів В.Голобородька, зокрема твору «3 дитинства: Спрага». Копітку роботу комбайнерів оприявнює метафора «веселий погляд 
3-під колосся брів», яка установлює «горизонт очікування» казкового сюжету з чарівною річчю:

... Як не хочете пити небесної блакиті, то я виліплю із сония, із променів, із пшениці не простого глечика, а золотого і принесу води... [5, с. 20].

Зводячи у сценці з побутового життя фольклорні мотиви, В. Голобородько намагається створити новий архетип казки. Не чарівна річ має стати тут першоелементом фантастичної оповіді, а, навпаки, - її відсутність і завдяки цьому - задоволення, яке отримує герой від подолання перешкод самотужки; не «золотий» глечик із пшениці та сонця, а звичайне відерце здатне напоїти спраглих хліборобів.

Пантеїстичними інтонаціями насичено вірш В. Голобородька «Золоті глечики груш» - спогад маленького хлопчика про загиблого на війні батька, про його мирну роботу в полі. Поетика голосіння виявляється у ключовому мотиві пошуків померлого:

Підійшов - / комбайн стоїть / червоним безкрилим птахом. / Підійшов, / кличу батька - нема. / Я заглянув у пшеничне колосся нема. / Я заглянув на дно дороги - нема і сліду. / Я заглянув під одежу дерева - нема. / Я спитав у щуки, / яка хотіла проковтнути сонце не бачила. / Я спитав у річки - не бачила... [5, с. 45].

Маленький герой В.Голобородька відчуває особливо міцну духовну злютованість із батьком на грунті хліборобської праці: «...ми удвох слухали б хлюпіт ниви, / шурхіт пшеничного зерна у бункері / та нетерпляче очікували б зерновозок із току, / а іще я збігав би до криниці по воду...». Проте він, на відміну від «дорослих» оповідачів, не просто чекає на повернення батька, а внутрішнім зором убачає його реінкарнацію в стихіях землі та збіжжя:

Я не оратиму землі - бо тобі ж болітиме!

Я не сядуна трактора - тобі ж важко буде!

Я не коситиму пшениці - бо то ж твоє волосся!.. [5, с. 46].

Бінарна опозиція «смерть - безсмертя» вносить у культурологічні поезії В. Голобородька елемент перевтілення у суфійському дусі - глина, на яку перетвориться людина по смерті, та глек, який із неї виліплять [17, с. 405; 26, с. 205]. Специфічною інтерпретацією цього мотиву $\epsilon$ вірш «Кажу вам таку собі баладу». Заголовок знаменує декілька змістових мікрорівнів оповіді - у ньому слова «кажу вам» передбачають звернення до читачів, 
традиційне також для казки, а «така собі» - знак іронічного витлумачення мовцем свого оповідання як балади. Сюжетна основа твору кодується в «любовній історії» неживих предметів:

У криниці жив глечик / закоханий у воду

ненавидів уста / які воду цілували

ненавидів руки / які інтимність порушували

лякався як забирали воду / з його обіймів...

Глечик і вода є промовистими символами безнадійно закоханих, витлумачених у суфійському дусі. Характерними для твору В. Голобородька $\epsilon$ іронічне обігравання баладного мотиву самогубства та метаморфоза як його різновид:

Вирішив утопитися

а вода покохала другого глечика... [5, с. 153].

Характерно, що цей самий мотив, матеріалізований у численних реальних і метафоричних «глечиках» поета, підноситься до рівня сутності людини та їі безсмертя (рання поезія «Глечик на двох»):

Улітку-літечком / ми збирали з дівчиною суниці. / Глечик був один на двох... / А потім дівчина зникла, / вона упала в траву / і пропала...

У цьому вірші, як пізніше - в «Золотих глечиках груш», концептуальним $\epsilon$ мотив повернення людини у природну стихію: «... ï̈ тіло стало травою, / очі - росою, / i щоки стали ягодами». I, віднайшовши одне одного у довкіллі, персонажі «про глечик... геть зовсім забули». Тому дедалі частіше зазначена деталь у Голобородькових віршах із автологічної (найменування речі) перетворюється на металогічну (порівняння, метафору): глиняні глечики рік («прихильності...»), пакіл неба цвіте глечиками хмар («Спіймане сонечко»), твоя квітка - маленьким глечиком («Квітка: весняний первоцвіт»). Часто в цьому образі символізується мистецтво:

В кімнаті де було безліч глечиків

різних країн (викопні і новітні)

різних форм і кольорів

я дуже захотів води і не міг ї̈ знайти [5, с. 148].

Перші рядки цитованого вірша «Гостина у народної художниці Грузії Олени Ахвледіані» суголосні та водночас контрастні до ярмаркового опису: «Яке ж бо то свято, коли гончар-горшковіз складає на хурі, обплетеній хмизом, ... глечики, макітри, горщики, горнята, ринки, миски, покришки, свищики, монетки!.. Здається, святкує вся земля, вся природа переливається незбагненною веселкою» [див. 3, с. 22-24]. Атмосферу помешкання художниці інтимізовано настільки, що 
й сама господиня, й їі гість - ліричний оповідач «сиділи в глечиках» із грузинської та української глини. Це дозволяє говорити про інтерпретацію екзистенціалістського мотиву «мушля» (Е. Йонеско) крізь призму секретів художньої майстерності:

Ваш глечик був кольору світлої мудрості

і інкрустований геніальністю

а мій глечик був зелений

і на боках висіло листя...

Віддавна гончара порівнювали з деміургом - у його руках глечик нагадує жіночу постать, а «квіти... наносяться 3 такою віртуозною легкістю, що створюється враження космічного руху» [3, с. 36]. «Секрети гончарського ремесла» вербалізуються в поезї «Ліплення глечиків»:

У чоловіка на прізвище Гончар / запитую, як ліпити глечики. // «Набираюу рот глини / і випльовую глечики, / мов гарбузяче насіння» [5, с. 180].

Мовець із прикметним прізвищем Гончар - збірний образ представника цього ремесла, що таємницю своєї творчості пояснює алегорично, подібно до Мікеланджело: «Беру брилу мармуру i відтинаю від неї все зайве» [2, с. 498]. 3 другого боку, варто зважити на символіку слини як видового поняття символу води: «Слина... дуже плодюча й має чародійну силу, ставши взагалі символом родючого й очищального дощу... Як дощ прочищує Небо, так і слина очищує від усього злого» $[19$, с. 44]. Відтак у не вельми «естетичному» способі виготовлення посуду поєднано символи «гончар-деміург», «слинаоберіг» та «глечик-оберіг», які можна розглядати частинами більшого символічного комплексу «земля-вода».

Мистецькі образи у вірші «Катерина Білокур: виготовлення пензлика», заломлені крізь вільну віршову форму (чергування двота трискладових розмірів із неметричними рядками), показують хвилювання героїні, спонтанну символічність її світобачення:

Подивиться на кота і подивиться на кота.

«Котику мій, братику!»

А той сидить на припічку

Розцяцькований, як опішнянський глечик:

І калачики, і королевий цвіт, і чорнобривці

По ньому цвітуть [5, с. 285].

Привабливість анімалістичного образу кота для адресата поезї В. Голобородько підкреслює утвореним за зовнішньою подібністю порівнянням «як опішнянський глечик», викликаючи в реципієнта 
асоціації 3 багатобарвністю, пишністю, розмаїтою рослинною декоративністю, притаманною кераміці Опішні. Іншими словами, ліричний оповідач «на одній стеблині вирощує соняхи, дзвіночки, ромашки і лілії небачених форм» [4, с. 6-7], переймаючи «білокурівську» манеру писання. Тому образ схожого на глечик кота - показ суперечності між народним мистецтвом і життям, вияв полеміки «з тими, хто все, навіть функції мистецтва, зводить до «корисності», до примітивної заангажованості» [9, с. 37]:

«Що мені з ним робити, - скрушно промовить мати...

мишей не ловить, тільки дурно годуй,

цілими днями на припічку глечиком сидить,

хоч би на город вибрався та горобців

від соняшників відлякав,

стрижуть його на віхті, а він

хоч би шкрябнувся тобі...».

Доцільно зауважити, що й мати у вірші дивиться на кота «очудненим» поглядом, називаючи його «глечиком», хоча й не помічаючи на ньому квітів [16, с. 61].

Поезії Голобородька, які за ключовий мотив мають керамічні вироби, свідчать про синтез чималої кількості культурних концептів у мікрокосмосі реалій. Передусім це традиції чеського «поетизму», для якого характерна «поетика деталі» [12, с. 233], та східної поезії: за її жанровими канонами, згадані в оповіді річ, назва або ім'я стають художніми деталями загальної картини світу. Крім цього, у мініатюрі «не дивуйся...» наявний і вітменівський епічний елемент, завдяки чому вірш прочитується як загадка з відгадкою «символ»:

не дивуйся / це хтось розбив глечик навпіл / і роздав нам по половині / тобі половину / і мені половину // нам шукати одне одного / щоб напитися води / з одного глечика [5, с. 170-171].

Розпочинаючи від «глечика» як сенсорної деталі, В. Голобородько підносить ідею поезії до утвердження глибинних духовних засад людського буття. У свідомості ліричного оповідача (або оповідачів) образи, пов'язані 3 витворами декоративноприкладного мистецтва, розгортаються у метафору універсуму, деміургами якого $є$ вони самі. Завдяки такому поглядові автор доводить, що світ природи тісно сполучений зі світом людини, виражаючи ідею відродження пантеїстичного світогляду як взаємин людини та довкілля. 
Тому духовний і естетичний досвід поета, привнесений у структуру поетичної «історії речі», забезпечує численним зоровим образам повноцінне існування в контексті словесного виразу. Слово-символ як проміжна ланка між живописним образом предмета та його поетичним осмисленням концентрує породжені ним у автора та читача асоціації в єдиний комплекс духовного сприйняття. Завдяки цьому в українській культурі XX століття поновому утверджується бачення людини-у-світі як світу-в-людині.

\section{2. Актуалізація принципу «золотого перерізу» у вільному вірші Василя Голобородька}

У давнину числам приписували магічний зміст. Приміром, одиниця вважалася символом єдності всього сущого, якимось абсолютом. Двійка відбивала світобудову в бінарних опозиціях «матерія - дух», «чоловік - жінка», «день - ніч» тощо. До містичних результатів приводило також застосування запозиченого в математики поняття пропорції (числове співвідношення між частинами одного цілого). I найзагадковіший, найбільш легендарний й найчарівніший серед них - золотий переріз, що вплинув також і на сучасне мислення. Суть його в тому, що більша частина відноситься до меншої, як усе ціле - до більшої [13; 20; 24, с. 25; 28, с. 457-458].

Якщо вибудувати ряд золотого перерізу, то співвідношення одного відрізка до іншого матиме сталу величину. Коли взяти відрізок за одиницю і поділити його в золотому перерізі, то більший відрізок дорівнюватиме 0,618, а менший - 0,382; цю операцію (поділ меншого відрізка у тому ж співвідношенні) можна повторювати, дістаючи при цьому ряд золотого перерізу [13].

У приблизному, побутовому варіанті пропорція золотого перерізу - це приблизно $8: 5$, а ще точніше - $13: 8$. Математики вирахували це число точніше: десяткове розкладання числа «фі» (числа золотого перерізу) має вигляд 1,61803398(...), а для зручнішого користування його скоротили до 1,618. Це число має багато інших дивовижних властивостей.

Однією з них є спостережений упродовж останніх двох століть факт, що за принципом «золотого перерізу» побудовано найталановитіші витвори світового мистецтва. Так, Е. Розенов у статті «Золотий переріз у поезії та музиці» стверджував: «Золотий поділ міг би: установлювати у музичному творі витончене, сумірне відношення між цілим та його частинами; бути спеціальним місцем 
підготовленого очікування, суміщаючись із кульмінаційними пунктами <..> та з різнорідними провідними, з погляду автора, ефектами; скеровувати увагу слухача на ті думки музичного твору, яким автор надає найбільшого значення, які прагне поставити у відповідність між собою» [23, с. 76].

Сучасний український культуролог Олександр Пустовіт із позицій «золотого перерізу» грунтовно проаналізував низку шедеврів російської літератури (трагедію «Моцарт і Сальєрі» О. Пушкіна, «Приморський сонет» Анни Ахматової), що дало йому підстави констатувати: «Коли природні золоті пропорції виявляються у мистецтві (чи то внаслідок свідомого розрахунку автора, чи то продиктовані інтуїцією), це можна трактувати як спосіб наслідування природи. Тобто якщо художник свідомо надає своєму творові «золотих пропорцій», це... буде наслідуванням зовнішніх форм природи - шлях, який веде до кризи. Однак, творячи цілком вільно, будучи, за Платоном, у несамовитості, художник також може створити шедевр, позначений золотою пропорцією» [21, с. 497]. Зокрема, учений дійшов висновку про те, форма сонета визначається доктриною краси як співмірності, позаяк у ньому точка «золотого перерізу» випадає саме на межу між катренами та терцетами, точніше - на середину дев'ятого рядка [21, с. 643].

Кібернетик Олексій Стахов у недавно опублікованій зі співавторами книзі «Код да Вінчі та ряди Фібоначчі» (2007) піддає аналізові 3 «золотих» позицій не лише лірику О. Пушкіна, а й «Бородіно» М. Лермонтова та «Витязя у тигровій шкурі» Шота Руставелі, виразно наголошуючи на ролі «золотого перерізу» як маркера кульмінації у віршовій оповіді [24, с. 211-216].

Водночас неможливо не помітити, що досі «золотий» розбір пристосовували тільки до метричної поезї (римованого та білого вірша). У зв'язку з цим виникло питання: чи є принцип «золотого перерізу» концептуальним для верлібру, на перший погляд дезорганізованого та дискретного за стильовими характеристиками. Тому мета другого підрозділу - виявити «золоту» пропорцію у побудові низки поезій «білокурівського циклу» Василя Голобородька (проаналізована у першому підрозділі поезія «Катерина Білокур: виготовлення пензлика», а також «Катерина Білокур: піжмурки квітів», «Півонії: автопортрет із Катериною Білокур») та схарактеризувати їі місце у творенні гармонії витворів образотворчого й словесного мистецтва. 
На думку А. Макарова, «Катерина Білокур належить до числа тих митців, які ретельно вивчають найскладніші форми рослинного світу, до числа тих, хто черпає своє натхнення з майже наукового знання природи» [27, с. 11], завдяки чому дослідник робить слушний висновок, що найближчими до творчості художниці виявляються традиції наукового і мистецького синкретизму.

3 чого розпочинати картину? Всю інформацію з цього питання художники втратили через непотрібність; хіба тільки лишилася настанова для майстрів, котрі беруться до вишивання картин, починати строго 3 центру. Єдине, що було відомо будь-якій освіченій людині, - це числовий зв'язок побудови всього сущого у природі, відкритий Піфагором. Зв'язок, на який натякав ще Платон, твердячи, що суть краси - у співвідношенні частин із цілим та одна 3 одною («золотий переріз»). Кожен талановитий художник відчуває ці співвідношення, інтуїтивно виходить на них і пише, так би мовити, «у золоті» $[24$, с. 100]. Ця теза $\epsilon$ справедливою щодо творчого доробку Катерини Білокур.

Характерною культурологічною візією В. Голобородька стає переплетення двох видів мистецтва - живопису та поезії, що виявляється в назвах віршів. Ми ж додамо, що це переплетення грунтується на третьому виді мистецтва - народнопісенній творчості, адже саме її образи (котик-братик, дівочі вінки, барвінок, волошка, чорнобривці) і наближені до них індивідуально-авторські «білокурівські» (цар-Колос, квіти, що грають у піжмурки, як пустотливі діти) стали прототипами «квіткових ікон», за визначенням Ірини Конєвої [27, с. 30].

Мистецька синестезія зумовила версифікаційну структуру Голобородькового вірша, який за жанровою семантикою можна назвати філософською прелюдією до творчості. Це - верлібр із нерівновеликими синтаксичними періодами, повторами, прямою мовою, що відбиває неспокій у думках героїні:

Подивиться на кота і подивиться на кота.

«Котику мій, братику!»

А той сидить на припічку

Розцяцькований, як опішнянський глечик:

І калачики, і королевий цвіт, і чорнобривці

По ньому цвітуть [5, с. 285].

Рівень інтуїції, творчого натхнення, пориву творчості передається через низку характерних художніх деталей і утворює 
фабульну канву поетичної оповіді. Варто зауважити й незвичайну архітектоніку вірша, де кількість рядків наступної строфи («лесси», за дефініцією 3. Черни) має послідовність 6 - 10 - 4 - 7 - 11, репрезентуючи «золотий» гармонійний поділ твору на дві частини: першу, у якій ідеться власне про виготовлення пензля, та друга про долю кота, по суті, не потрібного нікому: «Що мені з ним робити, - скрушно промовить мати...// мишей не ловить, тільки дурно годуй, // цілими днями на припічку глечиком сидить, // хоч би на город вибрався та горобців // від соняшників відлякав, // стрижуть його на віхті, а він // хоч би шкрябнувся тобі...».

Для поезій такого гатунку притаманним $\epsilon$ ракурс не «побаченої», а «відчутої» деталі, яка згущує враження, збирає їх в одну точку й тому може перерости у велику емоційну силу. У «Виготовленні...» ця деталь - пензлик, який містить асоціацію «малювання», а що творчий задум іще не втілено - пензлик $є$ прихованою метафорою мальовничості світу, барви кожного окремого предмета чи істоти.

3 цієї деталі кристалізуються моменти, «золоті» для кожної окремо взятої строфи при діленні кількості наголосів на 1,618:

1) «опішнянський глечик»;

2) «розквітають о різній порі року»;

3) «готовий пензлик»;

4) «сусідські коти його лякаються»;

5) «хоч би на город вибрався»

(тут і надалі «золоті слова» виділено напівжирним шрифтом).

Містичність цього ряду полягає в тому, що значною мірою ці «золоті» моменти відбивають долю та світогляд самої Катерини Білокур (очуднене довкілля, живописна творчість - з одного боку, неприйняття оточуючими їі потягу до малювання - 3 іншого). Внаслідок цього до віршованого оповідання введено неоднозначний за семантикою анімалістичний образ - кота. Не випадково саме на цей образ припадає точка «золотого перерізу» новелістичний контрапункт, який дещо коливається залежно від кількості рядків, послідовності складів і наголосів. Так:

38 рядків : 1,618 $\approx 23,5$ («...сусідські коти його лякаються...»);

126 наголосів : 1,618 $\approx 77,8$ («...свого племені не визнають»);

368 складів : $1,618 \approx 227$ («...сусідські коти його лякаються...»).

А відтак можна зробити висновок, що цитований ліричний портрет Катерини Білокур при гармонійному аналізі актуалізує вкорінений у романтизмі мотив нерозуміння митця натовпом - 
«золота пропорція» ознаменована одночасно 23-м, 24-м та 25-м рядами. Тому можна говорити про те, що у цьому вірші йдеться не лише про підготовку до втілення творчого задуму, а й про елемент страху перед «натовпом» та рішучість його подолати.

Очуднене світосприйняття, явлене в картинах Катерини Білокур, передається й ліричному оповідачеві та персонажам В. Голобородька, який за допомогою словесного виразу робить конкретний твір образотворчого мистецтва відкритим для подальшого осмислення.

Поезія «Катерина Білокур: піжмурки квітів» - своєрідний поетичний аналог твору художниці «Квіти за тином». Передусім слід зауважити, що гармонійний аналіз цієї картини виявляє точку «золотого перерізу» у півонії. Ці квіти Б.-І. Антонич на початку 1930-х років стверджував символами непереможної молодості: «на чорнім тлі, мов кров трагічна, півоній молодість червона». В. Голобородько своїм ліричним «автопортретом із Катериною Білокур» закріпив значення цього символу, - рядок «півонії водили її рукою із пензлем» є «золотим» у першій строфі цього вірша, а разом із концептом «дивилися у дзеркало малярчиного погляду» в другій вони творять точку «золотого перерізу» цілого вірша:

Може, оті передвоєнні картини

були передчуттям півоніями того часу,

коли вони вмруть -

для загиблих на війні навічно,

для живих на невизначений час? [5, с. 347].

Своєю чергою, у «Піжмурках...» півонія невидима у слові, проте наявна як прихований образ у семантичному полі «квіти». Тому можна зробити висновок, що це ще одна ліро-епічна розповідь про мистецький задум та його втілення:

Квітка ховається за квітку, // грається з глядачем у піжмурки, // не з'являється доти, доки їі не назвеш:

«Ти, квітко блакитна, що в'єшся все вгору та вгору, // твориш своїм цвітінням перед очима стіну, // тоді вже не знаєш, чи то квіти, чи небо, - // кручені паничі...

Ти, квітко блакитніша, що ростеш при дорозі, // подорожніх виглядом своїм звеселяєш, // тих, хто повертається з поля, // помахами блакитної хусточки проводжаєш, - // волошка...

Ти, квітко найблакитніша, що стелишся // низенько при землі, // щоб і мертві небо побачили, - // барвінок...» [5, с. 344-345]. 
Кольорообраз у цьому вірші показано в стані градації, вираженому через утворення ступенів порівняння, загалом невластивих для відносного прикметника, яким і $\epsilon$ «блакитний», причому що інтенсивніший відтінок, то нижча квітка - від виткого крученого панича до барвінку, що стелеться по землі. Таким чином майстриня намагається пов'язати на полотні в одне ціле горішній, земний та підземний світи - Прав, Яв і Нав, яруси прадавнього Дерева життя. I не вадить, що «квіти - городні, берегові, польові, лісові - різночасові за порою цвітіння, раптом опиняються поряд» $[27$, c. 12$]$, адже таке зміщення в часі працює на показ художньої ідеї - єдності буття природи-в-людині та людини-в-природі.

Як і у «Виготовленні пензлика», «золота пропорція» у «Піжмурках квітів» випадає на середину 24-го рядка (за ідентичної кількості рядків - 38):

...малярка водила пензлем (23)

із набраною ультрамариновою фарбою, на полотні (24).

Проте, на відміну від попереднього твору, «золотий переріз» за порядком наголосів та складів уміщується в той самий синтаксичний період: за складами він випадає на слово «квіти» у 25-му рядку, а за наголосами - на слово «фарбою». Майже симетрична архітектоніка вірша: послідовність строф за числом рядків становить 3 - $16-(12+4)$ - 3 (третю та четверту доцільно трактувати як одне естетичне ціле), а в кожній окремій строфі «золотими» ключовими образами $є$ такі:

1) «грається з глядачем у піжмурки»;

2) «помахами блакитної хусточки проводжаєш»;

3) «фарба щезала»;

4) «хоч і не вороже»;

5) «стали рівненько за тином».

У цьому чергуванні слів виявляється «конспект» вірша, його першооснова - від гри у піжмурки, яка тлумачиться елементом дисгармонії, через «зникнення фарби» як інший, поряд із «котом опішнянським глечиком», символ «елітарності» мистецтва Катерини Білокур і до квітів, які «стали рівненько за тином». На цих «золотих» словах раз у раз наголошує ліричний оповідач «критиків» художниці він називає «чужинцями» та пояснює їхні дії іронічними «вченими» висловами:

Для чужинців, які пильно стежили, // як малярка водила пензлем, //... квіти були непомітні...// Малярчине заняття покваліфікували 
як непрактичне // і таке, що не має сенсу, // хоч і не вороже для них, // тому залишили її в спокої [5, с. 345].

Отже, «Піжмурки квітів» - це також рефлексія на тему Слова, сила якого робить ілюзорне реальним, невидиме - видимим, хаотичне - впорядкованим:

...варто було малярці назвати квіти своїми іменами,

як вони стали рівненько за тином,

як пустотливі діти, і зацвіли блакитно [5, с. 345].

Творчий задум та його реалізація постають також у третій поезії «білокурівського» циклу В. Голобородька - «Катерина Білокур: завивання вінка». За даними культурології, вінок - символ сонця, неба, року, кола; він також уособлює вінчання Бога та Богині, що $\epsilon$ народженням нового світу. У вірші праця на землі показується як частина праці художника - вирощування квітів, яке передує їх малюванню:

З ранньої весни готується вити вінок:

вибере коло хати сонячну місцину,

скопає глибоченько, заскородить рівненько,

яку квітку посіє, яку пересадить,

чистенько прополе, дбайливо виполиває... [5, с. 372].

Саме малювання квітів показано прийомом троїстої градації, завдяки якому мисткиня показується як деміург свого довкілля: «... принесе мольберта, // поставить біля білої квітки // і перемалює ії на полотно, // буде перша квітка на віночок». Показ творчого процесу вдало доповнюється звукописом:

Літо вплітає квітами у вінок,

летіння літа зупиняє пензликом.

Але літо минає -

вінок недомальованим лишається, «хай на друге літо домалюю».

«Золоті» слова кожної окремої строфи, як і в попередніх поезіях, відбивають ідею процесу малювання та його нескінченності в часі «перемалює» (1-ша строфа, 8-й рядок); «літо вплітає» (2-га строфа, 4й рядок); «рік до року» (3-тя строфа, 7-й рядок); «кожної наступної весни» (4-та строфа, 2-й рядок). Однак при підрахунку «золотої пропорції» цілого тридцятирядкового вірша виявляється, що вона випадає на середину 19-го рядка - «вінок недомальованим лишається», як містична фігура недомовленості (незавершеності 
малюнка). Тут вона сполучається з ідеєю циклічності часу, вираженою образом вінка, а ще - колоподібним ритмом верлібрових періодів:

Квітку до квітки, / день до дня, / місяць до місяця, / рік до року, -

в'є дівочий вінок [5, с. 372-373].

Дівчина, яка «починає дівування кожної весни» та «стоїть... посеред вічного літа», - космогонічна постать творця, архетипне втілення Великої Матері, «узагальнене зображення митця i мистецтва» [9, с. 39]. Оксиморонну на позір постать «дівчиниМатері», яка, за Голобородьком, «малюванням скасувала відцвітання, щоб було вічне літо», підкреслює метафоричний образ «квіти - діти» у символічній парадигмі «безсмертя».

Подальше дослідження законів «золотого перерізу» в поезії В. Голобородька дасть змогу установити їхню справедливість для вільного віршування (попри його позірну безсистемність та ритмічну дисгармонію), виражену передусім у способі відновити через вільну форму єдність музики, поезї та малюнка.

Тому актуальним стало завдання поглянути на творчість В. Голобородька у ракурсі поетики дитячого малюнка, його композиційних та кольористичних особливостей, реалізованих у поетичному творі.

\section{3. Образність дитячого малюнка у поетичному макрокосмосі В. Голобородька}

Ігровий аспект художньої творчості - одне 3 найважливіших джерел естетичної насолоди. Саме гра сполучає духовні сили людини в їх активності, необхідній для творчості. Гра - це модель творчості, настрій на неї, їі передбачення. Насолода від процесу творчості, від реалізації творчого потенціалу та самоствердження особистості у грі поєднується з задоволенням від не-скутості уяви, відсутності утилітарної необхідності й водночас організованості, наданої вільно прийнятими правилами гри, у порухах почуттів, вольових імпульсів та інтелекту, сполучених у спільний духовний комплекс [11, с. 333; 25, с. 272-273].

Дитяча творчість, передусім малювання, - динамічне, воно різноманітне на різних періодах розвитку. Процес - малювання як вияв творчої активності - не менш важливий для дитини, ніж результат (закінчений малюнок). Відокремлений від особистості автора, малюнок набуває нового значення: він не лише продукт дитячої творчості, який може багато розповісти про свого творця, 
а й об'єкт іншого виду художньої діяльності - експонування, вивчення, колекціонування, а також інтерпретування словесного.

I тут особливої ваги набуває такий концепт, як сув'язь образних елементів «наївного» дитячого малюнка у «дорослій» поезії. 3 раннього віку постає уявлення маленької людини про навколишній світ, витворене за допомогою експресивних поетичних символів - графічних i словесних. Природна допитливість спонукає малюка до багатьох власних відкриттів, які він намагається зафіксувати у малюнках; його фантазія вибудовує несподівані формозмістові єдності, оригінальні причиннонаслідкові зв'язки $[1$, с. 434]. А мовно-словесна гра збуджує інтерес до довкілля та усвідомлення свого місця в ньому, поступово вводить дитину у сферу наукових і культурних проблем сучасності.

Саме тому, обгрунтовуючи зацікавлення у малюванні, діти іноді виявляють «секрети» власної творчої лабораторії з урахуванням суто психологічних моментів: Люблю малювати картини фарбами; Люблю малювати речі; Люблю малювати, бо можна фантазувати; Подобається гратися й малювати, виготовляти [географічні] карти; Люблю розмальовувати при світлі нічника, мені подобається, коли у кімнаті затишно [цит. за 6, с. 31].

Що саме люблять малювати діти? 3 розмаїття тем можна виокремити універсальні, певною мірою архетипні для багатьох: сюжети з повсякденного життя; пейзажі, натюрморти, зображення тварин; образи героїв книг, казок, кінофільмів, анімаційних фільмів; історичні, міфологічні, біблійні сюжети; «родинні портрети», зображення рідних і друзів. Іншими словами - світ, який дитина бачить у рідному домі та поза ним, про який чує з фольклорних і писемних літературних творів.

Тому мета третього підрозділу роботи - на основі детального прочитання поезій В. Голобородька, у яким чільним образотворчим концептом $\epsilon$ «малювання», утвердити визначальну роль синтезу мистецтв у пізнанні дітьми рідної природи, менталітету українського народу, а також установити специфіку проникнення дорослого поета у таємниці дитячого світобачення, передусім завдяки вільній віршовій формі.

Словесна інтерпретація дитячого малюнка у творчості новітніх українських поетів виражається в непересічній верлібровій інтонації, яка символізує творчий неспокій юного художника. Особливих успіхів у цьому досяг В. Голобородько. Якщо 
придивитися до його віршів «Хлопчик малює літо», «Зустріч пташок», «Між двома деревами...», «У жовтім колоссі...», важко не помітити їхньої типологічної спільності з «дорослими» за змістом поезіями, заснованими на синтезі слова та малюнка («Колекціонер кольорових олівців», «Що написано між рядками», «Інтер'єр із годинником», «Катерина Білокур: піжмурки квітів», «Катерина Білокур: завивання вінка»).

За свідченнями дослідників, Голобородькові словесні малюнки підкреслено декоративні, вони нагадують простодушно-дитинне й мудре водночас бачення Марії Приймаченко, декоративну розкіш її живопису [див. 18, с. 203], співжиття реальних та ілюзорних тварин («ушаток» i раків, «сміходій» і комарів). Так само у творах Голобородька одна-єдина істота або річ (людина, яблуко, поле, птах) може зазнати багатопланової метаморфози, показаної через каскади однорідних присудків на взірець коміксу або анімаційного фільму, складеного з дитячих малюнків.

Фольклоризм «дитячої країни» Василя Голобородька різноманітний, глибокий. Митець переплавляє сюжети, мотиви, образи, окремі елементи народних казок, загадок, замовлянь, рідко вдаючись до прямих ремінісценцій, проте повсякчас підпорядковуючи фольклорну наративну традицію авторському задумові [див. 29, с. 265-266]. Для цієї мети автор удало добирає зображально-виражальні засоби дитячої творчості, насамперед образотворчого мистецтва.

Першим промовистим прикладом цьому $\epsilon$ поезія «Хлопчик малює літо»:

Кавуни зелені

котять півні

по жовтій нитці,

простягненій під вишнею,

на якій самотній птах гойдається на вершечку...

Колір характеризується найбільшою виразністю з-поміж усіх засобів дитячого малювання, гармонія кольору у зображенні грунтована на узгодженні великих барвистих плям, а нюансування відтінків приходить значно пізніше [10, с. 112]. Колорит цитованого вірша - сільського пейзажу - визначається чотирма яскравими барвами: зеленою, жовтою, червоною та білою. Останні дві не називаються прямо, а виступають прихованими метафорами у наступному після цитованого п'ятивірша дистиху: «краплі вишень / 
забризкали стіну хати». У поезії розташування рядків зумовлює контрастні переходи між кольорами, характерні для дитинного світобачення, явленого на папері. Очевидним також $є$ очуднення - в образі-загадці «жовта нитка попід вишнею» (стежка).

Двовимірність простору дитячого малюнка на «архетипну» тему «Моя домівка» у словесній інтерпретації увиразнюється однією рухливою деталлю - птахом, який гойдається на вершечку вишні. Водночас слід зважити на широке коло інтертекстуальних мотивів у межах малого твору - «півні, що котять кавуни», суголосні 3 зайцями М. Вінграновського, які «котять передніми лапами по городах капусту в поле»; «самотній птах», який попервах викликає асоціації 3 верлібристикою В. Вірмена (лейтмотивним образом дрозда у численних його поезіях), у сприйнятті ліричного спостерігача постає солярним символом [17, с. 392]:

Туди-сюди

самотній птах гойдається,

мече кругле око на землю,

де кавуни зелені

котять півні [5, с. 68-69].

Ще одна «архетипна» тема дитячого малювання - «Зимові ігри», до кола якої входять катання на санчатах, лижах чи ковзанах, гра у сніжки, ліплення снігової баби тощо. В. Голобородько «ословлює» цю тему у замальовці, яку можна кваліфікувати «віршемвідлунням» минулої розваги, - «Зимовий вечір»:

Червоні вишні, розсипані на снігу, / дзьобає сорока із синього скла.

Це бачить дівчинка, що з ковзанки йде.

Пальто ї̈ у снігу, наче щоки, / коли б от медяник їла.

А в долонях у дівчинки / сорочі сліди / і червоні вишні [5, с. 237].

У яскравих синьо-червоних кольорах творено нову символіку вечора - червоні вишні, вірогідно «синоніми» зір, та синя скляна сорока, що ії можна тлумачити як світло ліхтаря або колір неба у погожий зимовий вечір. «Велике у малому» - макрокосмос довкілля, зосереджений у мікрокосмосі душі дівчинки, відбито в орнаментальній деталі «в долонях... сорочі сліди і червоні вишні», яка вочевидь $\epsilon$ народним візерунком, виплетеним на рукавичках.

Неабиякої популярності у дітей зажили кольорові олівці. Досвід вивчення дитячих малюнків цього типу показує, що досягти об'ємного кольору в олівцевій техніці можливо лише неквапливим методичним зафарбуванням, щільно та ритмічно укладаючи штрих 
до штриха. Навіть у творчості п'ятирічних дітей трапляються гарні малюнки олівцем, подекуди двома-трьома, а інколи й одним $[10$, c. 126]. Техніку «малюнка одним олівцем» нагадує Голобородькова мініатюра «У жовтім колоссі...», де перебіг відтінків жовтого символізується словесною грою, алітераціями:

У жовтім колоссі / живуть птахи з жовтими крилами / яких немає в жодного птаха

Повіє вітер / птахам захочеться полетіти / зніметься усе поле і полетить... [5, с. 137].

Домінування жовтого сполучено зі штриховим графічним вираженням, що ним показано ідею польоту, ідею співу (аналог нотного запису), розгортання метафоричного образу: «Щоб послухати жовтих пісень / змайструю клітку / і посаджу туди одного птаха». В одному з видань поезій Голобородька цитований твір має жанровий визначник «елегія» [див. 29, с. 293]. I це закономірно, адже ліричний герой тривожиться долею єдиного птаха, якому «боляче на самоті». Водночас «доросла» елегійна тональність твору суголосна 3 «дитячою» кольоровою гамою, що дозволяє говорити про те, що внутрішня драматургія всіх проаналізованих елегій розвивається за такою лінією: сум, меланхолія - несподіваний порив, осяяння - надія - злиття з природою - безсмертя (вічне повернення). Міфічна космогонія, закладена в елегійну оповідь вільної віршової форми, зумовила ії збагачення елементами фольклорної та молитовної поезії, а отже й певну сакральність [17, с. 176].

Такими рисами позначено один із зрілих творів - «Зустріч пташок», ідеєю якого стали ностальгійні спогади ліричного героя про дитинство, його будні та свята, передусім День Святого Миколая. Персонаж, аби надалі подаровані йому кольорові олівці «не замкнули в офіційний сейф» у якості музейного експоната, перетворює їх на істоти та стихії, від яких було запозичено їхні кольори:

замовкаю тоді, коли вимагають говорити -

жовтого олівця повертаю розквітлим купавкам,

говорю тоді, коли велено мовчати -

синього олівця пускаю водою в річку,

стою на місці, коли закликано іти вперед -

червоного олівия віддаю на сонце,

з болем просуваюся вперед, коли наказано зупинитися на місці з чорного олівця роблю пір'я весняному птахові, 
ненавиджу те, що оголошено всіма любленим рудого олівця дарую на шпаківню, люблю те, що у декого викликає зненависть зеленого олівця кладу травою на пагорб [5, с. 324].

I виявляється, що кольори, навіть «повернуті» природі, лишаються символом зв'язку часів - у дитинстві подарунок Святого Миколи, в юності - відбиток суперечливого буття ліричного персонажа, у зрілості - повернення до першоджерел (малюнок «Зустріч пташок»).

Штрихове олівцеве малювання, яким діти часто зображають дощ, вербалізовано у вірші «Нитяний заєць», що виявляє очевидну спільність наївного образотворчого мистецтва зі словесними фольклорними жанрами:

Вибіг із хмари / заєць, / довгий нитяний заєць.

Виплигує нитяний заєць / по вишитому літом колоссі...

Тарабанить нитяний заєць / у денця відер на тину...

Котить нитяний заєць / по дорозі сонця, / яких нікому не перелічити... [5, с. 26].

У метафоричному показі предмета чи явища загадка не оминає географічних назв, реалій живої природи, людського життя, предметів господарського і культурного вжитку певного народу [15, с. 28]. Тому В. Голобородько у канву своїх віршів уводить графічні мотиви, характерні (архетипні) для переважної більшості дитячих малюнків (сонце, хата, сад, дощ). Створивши власний унікальний образ «нитяний заєць - дощ», митець вписує його в український пейзаж, де «колосся вишите літом», і вивершує у прихованій метафорі прадавнього замовляння - закликання дощу: «Приніс нитяний заєць / курям зеленим - пшона, / дахам череп'яним - райдугу, / дітям - червоних маків сміху» та народної казки.

Чимало «дорослих» поезій не лише інтерпретують поетику статичного дитячого малюнка, а й підносять його до рівня анімаційного фільму. В іншому творі В. Голобородька «За святковим столом» виражений словами образ дитячого малювання отримує стрімкий динамічний характер, зумовлений метаморфозою:

Наш стіл / відчув свято / і став дивним деревом:

він пустив пагінці, / з них розквітли квіти /

(ті квіти були білими / завбільшки з тарілку)

і просто у полив'яних квітах / виросли яблука...

Якісний анімаційний фільм - вияв синтезу багатьох мистецтв [7, с. 17]: літературної творчості (написання історії), драматургї̈ 
(сценарій), образотворчого мистецтва (постаті героїв, тло, розкадрування), сценічного мистецтва (рухи героїв, зміни тла), кінофотосправи (зйомка), музики та звукозапису (озвучення готового фільму). «За святковим столом» Голобородька цілком відповідає цим умовам; сьогодні можна говорити й про створення за описаним сценарієм фільму засобами 3D-анімації - наприклад, перетворення пласких квітів на об’ємні яблука, або подальша метаморфоза людей, які зібралися біля столу:

Наші руки з розчепіреними пальцями,

як пташки, полетіли над столом,

збивалися десь посередині і дзвеніли...

Контекстуально-спровокований елемент жалоби («стіл знає, що нас було шестеро в сім'ї... ») відтінюється символікою весілля: «шосте [яблуко] моїй дружині буде» [5, с. 84].

Інший «мальований словом» анімаційний фільм Голобородька вірш «Між двома деревами ...», у якому вжито той самий прийом, що й у цитованому вище «Нитяному зайці»:

Між двома деревами / Два червоних півні б'ються,

Крилами до землі течуть, / I по найкращій у світі райдузі

Почепили на свої хвости / (на хвости дощу),

I пір'їну одну загубили

У городчик, щоб цвіли троянди... [5, с. 103-104].

Звичне передусім для сільської «дитячої країни» явище півнячий двобій із перших рядків поезії сенсорно відчувається саме як такий і тому напрочуд яскраво змальований (крила, які «до землі течуть», хвости-райдуги, загублена пір'їна). Не відразу реципієнтові приходить на думку розгадка на загадку, явлена в останніх словах:

Кохана, не зачиняй віконце, / і ти побачиш, як іде дощ.

Природна допитливість спонукає як дітей, так і дорослих до багатьох власних відкриттів, що їх вони намагаються зафіксувати у спільних образотворчих працях, які надалі буде оприявнено у словах. Дитяча фантазія вибудовує несподівані формозмістові єдності, оригінальні причинно-наслідкові зв'язки, а мовно-словесна гра, оприявнена у віршах поета, збуджує інтерес до довкілля та усвідомлення свого місця в ньому, поступово вводить дитину у сферу наукових і культурних проблем сучасності. 


\section{Висновки}

Розпочинаючи від наскрізної сенсорної деталі, В. Голобородько підносить ідею кожного зі свої творів до утвердження глибинних духовних засад людського буття. У свідомості ліричного оповідача (або оповідачів) образи, пов'язані передусім із витворами декоративно-прикладного мистецтва, розгортаються у метафору універсуму, деміургами якого $€$ вони самі.

Відтак виявляються індивідуально-авторські інтенції у створенні образів митців (художників, гончарів, скульпторів), перипетій творчого задуму та послідовного його втілення. Ліроепічні за жанровими ознаками, філософські й подекуди містичні за звучанням розповіді, якими вони $\epsilon$ у Василя Голобородька, вимагають саме верлібру, його інтонації розмовного вислову, який дає читачеві імпульс до співтворчості, до спільного пошуку істин буття. «Білокурівський цикл» як синтез словесного та образотворчого мистецтв - витвір, який, окрім акцентування на сенсорних деталях, уповні відбиває ідею гармонізації форми та змісту через правило «золотого перерізу».

Послідовна реалізація принципів інтуїтивного добору композиційних елементів - строфо- та складоподіл, варіювання наголосів, синтаксична завершеність рядка або анжамбеман дозволяє В. Голобородькові залучити до формування контрапункту віршової оповіді широкий асоціативний ряд із містким словомсимволом, «золотим» для цілого твору. За «золотими словами» кожної окремої строфи виразно простежується не лише секвенція ключових ідей, «конспект» поезії, а й віхи життя та становлення індивідуального стилю Катерини Білокур, етапи створення конкретного живописного полотна.

Насамкінець, поетизуючи у словесному творі дитячий малюнок, В. Голобородько по-своєму дотримується євангельської настанови: «Будьте як діти, щоб увійти у Царство Небесне». Саме тому дитина у його віршах часто $є$ діячем або оповідачем, навіть королем своєї «дитячої країни», а образи творяться завдяки спонтанним сенсорним асоціаціям, що іноді мають форму «бінома фантазії», в якому синтезуються слово та графіка. Це дозволило визначити макросвіт верлібристики В. Голобородька (як і загалом сучасної поезії, твореної на образній основі дитячого малювання) одним із виявів так званого «етносимволізму»: творчої інтерпретації української фольклорної символіки у вільновіршовій формі, яка 
завдяки нерегулярним ритмам залучає графічні символи та мотиви до нескінченного космічного руху.

\section{Список використаних джерел:}

1. Анализ и интерпретация произведения искусства: учеб. пособие / Н.А. Яковлева, Е.Б. Мозговая, Т.П. Чаговец и др.; под ред. Н.А. Яковлевой. Москва: Высшая школа, 2005. 551 с.

2. Антологія афоризмів / упоряд. Л.П. Олексієнко. Донецьк: Сталкер, 2004. 704 c.

3. Ганжа П. Таємниці українського рукомесла. Київ: Мистецтво, 1996. 320 c.

4. Гоберман Д.Н. Мотиви гуцульського керамічного розпису. Київ: Дух і літера, 2005. 184 с.

5. Голобородько В. Летюче віконце: поезії / вст. ст. І. Дзюби. Київ: Укр. письменник, 2005. 463 с.

6. Егорова М.С. и др. Из жизни людей дошкольного возраста: дети в изменяющемся мире. Санкт-Петербург: Алетейя, 2001. 239 с.

7. Красный Ю.Е., Курдюкова Л.И. Мультфильм руками детей: книга для учителя. Москва: Просвещение, 1990. 176 с.

8. Крутенко Н. Розповіді про кераміку. Книжка про глиняний горщик, полив'яну кахлю, цеглу та фарфорову чашечку. А також про тих, хто їх виготовляє. Київ: Либідь, 2002. 252 с.

9. Кузьменко О.В. Поетика Василя Голобородька. Донецьк: Східний видавничий дім, 2005.196 с.

10. Левин С.Д. Ваш ребенок рисует: книга о детском рисунке. Москва: Сов. художник, 1979. $271 \mathrm{c.}$

11. Лилов А. Към природата на художественото творчество. София: Наука и изкуство, 1979. 412 с.

12. Літературознавча енциклопедія: у 2-х т. Т. 2: Маадай-Кара Я-Форма / авт.-упоряд. Ю.І. Ковалів. Київ: ВЦ «Академія», 2007. 624 с.

13. Магія золотого перерізу. URL: http://ostriv.in.ua/index.php?option=com_content\&task=view\&id=447 5\&Itemid $=-5$

14. Мамардашвили М.К., Пятигорский А. Символ и сознание: метафизические рассуждения о сознании, символике и языке. Иерусалим: Хевирот, 1982. 359 с.

15. Мойсієнко А.К. «Без вікон, без дверей...»: про національнообразний світ української загадки. Урок української. 2004. № 7/8. С. 28-30. 
16.Науменко Н.В. Ліричні портрети Катерини Білокур. Українська мова та література в середніх школах, гімназіях, ліцеях $i$ колегіумах. 2008. № 4. С. 59-68.

17.Науменко Н.В. Серпантинні дороги поезії: природа та тенденції розвитку українського верлібру: монографія. Київ: Видавництво «Сталь», 2010. 518 с.

18.Никанорова О. Свято буття. Поезія - 89. Вип. 1. Київ: Рад. письменник, 1989. С. 202-210.

19.0гієнко Іван (Митрополит Іларіон). Дохристиянські вірування українського народу: історично-релігійна монографія. Київ: АТ «Обереги», 1994. 424 с.

20.Пропорційність і ритм. URL: http://komfort.lviv.ua/ article_info.php/articles_id/57/article/Proporciinist-i-ritm

21.Пустовит А.В. Этика и эстетика: наследие Запада. История красоты и добра: учеб. пособие. Киев: МАУП, 2006.680 с.

22.П'янов В. Визначні, відомі й «та інші...». Спогади, есеї, нариси. Київ: Укр. письменник, 2002. 463 с.

23.Розенов Э.К. Статьи о музыке. Москва: Музыка, 1982. 178 с.

24.Стахов А., Слученкова А., Щербаков И. Код да Винчи и ряды Фибоначчи. Москва: Питер, 2007. 320 с.

25.Столович Л.Н. Жизнь, творчество, человек: функции художественной деятельности. Москва: Политиздат, 1985. 415 с.

26.Хазрат Инайят Хан. Учение суфиев: сборник / пер. с англ. Н.В. Кияченко. Москва: Сфера, 1998. 352 с.

27.Червоних сонць протуберанці. Збірник мистецтвознавчих і культурологічних праць до 100-річчя Катерини Білокур. Київ: АртЕк, 2001.128 c.

28.Шейнина Е.Я. Энциклопедия символов. Москва: 000 «Издательство АСТ»; Харьков: Торсинг, 2002. 591 с.

29.Шутенко Ю. Фольклорна традиція та авторське «Я»: поезія Василя Голобородька: монографія. Київ: Наукова думка, 2007. 356 с. 